\title{
Efektifitas Pelatihan Teknik Pop-Up untuk Meningkatkan Kreativitas Pendidik Anak Usia Dini
}

\author{
Vivi Irzalinda*1, Devi Nawangsasi ${ }^{2}$, Sugiana ${ }^{3}$ \\ ${ }^{3}$ Program Studi PG-PAUD, Jurusan Ilmu Pendidikan, FKIP , Universitas Lampung \\ *e-mail: viviirzalinda@fkip.unila.ac.id ${ }^{1}$, devi.nawangsasi@fkip.unila.ac.id ${ }^{2}$, ana.sugiana@fkip.unila.ac.id ${ }^{3}$
}

\begin{abstract}
The creativity of teachers in learning process an important role in the world of education. Teachers are required to give more creative, innovative, informative learning process and attract students in order to produce the creative generations. In the realization process, the creativity training activities for PAUD teachers are needed. The purpose of this training is to find out the significant differences in pop-up training to increase the creativity of early childhood educators. The target participants of this training activity are PAUD teachers in Bandar Lampung. The number of participants was 25 teachers. The methods used in these activities, namely training, include the materials supplementation, simulation practices of pop-up media creation, as well as the assignment practice of pop-up technique, evaluation. The result of this training was that the average pre-test score was 53.12 percent increased to post-test results of 82.64 percent. Based on the results from significance tests, it can be concluded that there is a significant difference in the effectiveness of pop-up technique training to increase the creativity of early childhood educators. In conclusion, from this results it can be obtained that this training is able to provide knowledge and pop-up technique skills to increase the creativity of early childhood educators.
\end{abstract}

Keywords: creativity, pop-up technique, stimulation, media.

\begin{abstract}
Abstrak
Kreativitas guru dalam pembelajaran memegang peranan penting dalam dunia pendidikan. Guru dituntut memiliki kegiatan pembelajaran lebih kreatif, inovatif, informatif dan menarik peserta didik untuk mencetak generasi yang kreatif. Untuk mewujudkan hal tersebut, kegiatan pelatihan kreativitas bagi guru PAUD diperlukan. Tujuan pelatihan ini yaitu untuk mengetahui perbedaan yang signifikan pada pelatihan teknik pop-up untuk meningkatkan kreativitas pendidik anak usia dini. Sasaran peserta kegiatan pelatihan ini adalah guru-guru PAUD di Bandar Lampung. Jumlah peserta adalah 25 guru. Metode yang digunakan dalam kegiatan pengabdian ini yaitu pelatihan meliputi pemberian materi, simulasi praktek pembuatan media teknik pop-up, serta pemberian tugas praktek teknik pop-up, evaluasi. Hasil dari pelatihan ini adalah rata-rata nilai pre-test adalah 53,12 persen mengalami kenaikan menjadi hasil post-test sebesar 82,64 persen. Berdasarkan hasil uji beda dapat disimpulkan bahwa ada perbedaan yang signifikan efektivitas pelatihan teknik pop-up untuk meningkatkan kreativitas pendidik anak usia dini. Sehingga dari hasil yang didapat bahwa pelatihan ini mampu memberikan pengetahuan dan keterampilan teknik pop-up untuk meningkatkan kreativitas pendidik anak usia dini.
\end{abstract}

Kata kunci: kreativitas, teknik pop-up, stimulasi, media

\section{PENDAHULUAN}

Mutu pendidikan di Indonesia perlu untuk ditingkatkan, mengingat persaingan sumber daya manusia secara global telah terjadi. Dengan meningkatkan mutu pendidikan, maka sumber daya manusia Indonesia dapat bersaing secara global. Mutu pendidikan dapat meningkat ketika tenaga pendidik memiliki kualitas yang tinggi. Hal tersebut dikarenakan guru merupakan pemegang peran penting dalam dunia pendidikan. Guru di Lembaga PAUD dituntut untuk lebih kreatif dibandingkan dengan peserta didik. Guru yang memiliki kreativitas tinggi akan mencetak generasi yang kreatif pula, karena guru dapat memberikan kegiatan pembelajaran yang inovatif dan informatif, original, dan menarik pada peserta didik.

Csikszentmihalyi (1996) mendefinisikan pengertian kreativitas adalah beberapa tindakan, ide, atau produk yang berubah dari domain lama ke domain yang baru. Jadi orang kreatif adalah orang yang mampu berpikir atau bertindak berubah dari satu domain ke dalam domain yang baru. Kreativitas merupakan kemampuan atau kecakapan yang ada dalam diri seseorang, Hal tersebut berkaitan dengan bakat seseorang (Guilford, 1982). Berdasarkan 
penjelasan para ahli mengenai kreativitas, Sternberg dan Lubart (1999) berpendapat bahwa kreativitas merupakan kemampuan untuk bekerja dan menghasilkan sesuatu yang baru (orisinil, tidak terbayangkan sebelumnya) dan tepat (bermanfaat, memenuhi tujuan kerja yang diharapkan).

Kreativitas seorang guru PAUD sangat dibutuhkan ketika menyusun media pembelajaran, karena media pembelajaran menuntut kreativitas guru dalam menciptakan informasi yang informatif dan menarik untuk anak. Pada hakikatnya, proses pembelajaran yang ada di PAUD membutuhkan media pembelajaran pada setiap pertemuan. Sehingga, dibutuhkan banyak media yang sesuai dengan tema dan tujuan dari pembelajaran yang diberikan. Dengan kreativitas tinggi yang dimiliki seorang guru dapat menciptakan pengembangan media yang menarik dan inovatif, jadi guru tidak melulu menggunakan LKS yang disediakan Lembaga/Yayasan/pemerintah semata.

Kenyataannya berdasarkan hasil observasi kegiatan P4KA (Program Pengenalan Proses Pembelajaran dan Kompetensi Akademik) prodi PG-PAUD Universitas Lampung, di Lampung masih banyak guru yang hanya menggunakan LKS, media seadanya, media yang tidak sesuai dengan tema, dan lain sebagainya. Hal tersebut terjadi dikarenakan kreativitas guru saat ini sedang menurun. Hasil wawancara menyatakan bahwa sebagian besar guru kehabisan ide untuk membuat media pembelajaran yang menarik siswanya sesuai dengan tema. Selain itu, guru menyatakan tidak punya cukup banyak waktu jika ingin membuat media pembelajaran yang menarik karena dianggap sulit. Berdasarkan teori piaget yang menyebutkan bahwa pada usia 07 tahun anak pada tahap sensorimotorik dan pada tahap praoperasional belum terpenuhi dengan pembelajaran yang menggunakan bahan ajar LKS atau media seadanya. Hal ini dikarenakan pada usia 0-7 tahun anak belajar dari sentuhan dan penglihatan sesuai benda nyatanya. Jadi pada usia 0-7 tahun anak belajar dengan benda konkrit. Untuk itu, seorang guru dituntut untuk menciptakan dan mengembangkan media pembelajaran yang menarik dan informatif untuk meningkatkan pengetahuan peserta didiknya (Sabri, 2005 dalam Winarti \& Setiani, 2019).

Jenis media pembelajaran sangat bervariatif, seperti: audio, cetak, audio-cetak, dan multimedia. Namun, berdasarkan karakteristik perkembangan piaget tersebut, maka media yang cocok untuk anak usia 0-7 tahun adalah media cetak. Media cetak yang dapat disentuh, dirasa, dan dilihat lebih menarik anak untuk mengikuti kegiatan. Media cetak sendiri memiliki karakteristik sendiri, seperti: 1 dimensi, 2 dimensi, dan 3 dimensi. Menurut Solichah \& Mariana (2018) Media 3D yang digunakan pendidik PAUD dapat membentuk objek peserta didik dalam menerima semua informasi yang telah disampaikan guru, tidak hanya dalam teori tapi juga dapat dilihat bentuk dan simulasinya. Untuk itu, Barsihanor, Hafiz, KMR, \& Budi (2020) mengungkapkan(Solichah \& Mariana, 2018) guru PAUD dapat dengan maksimal menyampaikan informasi menggunakan media tiga dimensi (3D), karena media 3D juga dapat menarik dan membuat anak penasaran.

Pada dasarnya, media yang kurang menarik dapat menjadikan anak bosan dan malas untuk mencoba dan mempelajarinya. Seperti halnya media buku yang ditawarkan hendaknya dibuat secara kreatif agar menarik minat belajar anak (Widyaningrum, Pratiwi, \& Listiani, 2021; Matin, Ety Rohaety, \& Nuraeni, 2019). Pemilihan media kertas, warna, dan visualisasi gambar hendaknya menjadi sesuatu yang perlu diperhatikan. Gambar yang bernuansa tiga dimensi (3D) tampaknya menarik diberikan pada anak. Anak perlu dikenalkan buku dengan tampilan yang berbeda dari biasanya sehingga menimbulkan rasa penasaran untuk melihatnya. Tampilan gambar yang bernuansa 3D biasanya disebut dengan pop-up.

Bluemel \& Taylor (2012) memberi pengertian pop-up book adalah sebuah buku yang menampilkan potensi untuk bergerak dan interaksinya melalui penggunaan kertas sebagai bahan lipatan, gulungan, bentuk, roda atau putarannya. Pengertian lain menurut Montanaro (2009) dalam (Streit \& Erlyana, 2019) pop-up book merupakan sebuah buku yang memiliki bagian yang dapat bergerak atau memiliki unsur 3 dimensi. Pop-up lebih cenderung pada 
pembuatan secara mekanis bahan kertas yang dapat membuat gambar tampak berbeda baik dari sisi perspektif/dimensi, perubahan bentuk hingga dapat bergerak yang disusun sealami mungkin. Mendukung dari pengertian-pengertian diatas, Dzuanda (2011) dalam (Khamidah, Utaminingsih, \& Kanzunnudin, 2021) menjelaskan pengertian pop-up book adalah sebuah buku yang memiliki bagian yang dapat bergerak atau memiliki unsur 3 dimensi serta memberikan visualisasi cerita yang lebih menarik, mulai dari tampilan gambar yang dapat bergerak ketika halamannya dibuka.

Pop-up dapat memperluas daya imajinasi anak. Imajinasi terbangun dari referensi. Semakin luas referensi yang dimiliki seorang anak, semakin luas pula daya imajinasi anak tersebut. Kemampuan berimajinasi berjalan lurus dengan kreativitas anak. Buku pop-up dapat memperkaya referensi anak, baik dari isi ceritanya, maupun dari bentuk ilustrasi 3Dnya. Dengan pop up anak juga belajar dari susunan struktur ilustrasi 3D. Dari buku pop-up, anak-anak tak akan hanya membaca isi ceritanya, melainkan ilustrasi 3D yang lebih mencuri perhatian anak. Ilustrasi 3D merupakan susunan kertas yang dibuat oleh ahli dengan struktur tertentu. Hal tersebut bisa mengundang rasa penasaran anak tentang bagaimana ilustrasi 3D tersebut dibuat. Bahkan, struktur dan pola tertentu dari ilustrasi 3D merangsang untuk memikirkan logikanya. Hal itulah yang beperan sangat besar dalam membangun kreativitas anak. Media Pop-Up Book merupakan media pembelajaran yang dikembangkan sesuai kebutuhan (Lismayanti, Hamidah, \& Anggereini, 2016; Sari \& Kasiyati, 2018; Barsihanor, Hafiz, KMR, \& Budi, 2020).

Untuk itu, Pratiwi \& Amelia (2020) dan Winarti \& Setiani (2019) mengungkapkan popup dapat meningkatkan kreativitas guru, karena dalam mengembangkan pop-up banyak teknik yang harus dipelajari guru; materi/informasi yang akan disajikan dalam bentuk pop-up juga harus jelas; referensi bacaan guru harus ditingkatkan, dan ketika mengembangkan media ini, guru harus berfikir inovatif untuk membuatnya pada setiap tema pembelajaran. Berdasarkan dengan permasalahan diatas, maka tim tertarik melaksanakan kegiatan pengabdian masyarakat tujuan untuk mengetahui perbedaan yang signifikan pada pelatihan teknik pop-up untuk meningkatkan kreativitas pendidik anak usia dini.

\section{METODE}

Pelaksanaan kegiatan pengabdian masyarakat yang dilakukan oleh Program Studi PGPAUD Universitas Lampung menggunakan metode kuantitatif. Pelaksanaan pelatihan ini terdiri dari 3 tahapan, yaitu tahapan awal, tahapan persiapan dan tahapan akhir atau evaluasi. Sasaran peserta kegiatan ini adalah guru-guru PAUD di Bandar Lampung yang berjumlah 25 orang. Lokasi pelaksanaan pelatihan menggunakan aula TK Tunas Bangsa Bandar Lampung. Pertimbangan pemilihan lokasi adalah lokasi aula TK Tunas Bangsa Bandar Lampung terletak ditengah kota sehingga memudahkan guru untuk bertemu, serta aula yang luas.

Metode pelaksanaan pelatihan teknik pop-up bagi guru PAUD dilakukan dalam bentuk pre-test, pemberian materi tentang konsep kreativitas, manfaat kreativitas, strategi stimulasi kreativitas bagi guru PAUD, pengenalan pop-up, jenis-jenis teknik pop-up dan teknik pop-up bagi guru PAUD, dan kemudian praktek membuat buku pop-up untuk bahan ajar di PAUD. Penilaian evaluasi peserta yaitu dengan cara melihat langsung pada saat praktek, hasil karya peserta dan post-test peserta.

Tahapan kegiatan pengabdian dilaksanakan melalui beberapa tahapan, diantaranya yaitu:

1) Tahap Awal berkaitan dengan kegiatan persiapan pembentukan tim dan menentukan pokok masalah kegiatan pengabdian, menentukan kelompok sasaran, menentukan pokok materi pelatihan, menetapkan waktu, tempat kegiatan, survey lapangan, serta membuat pre-test dan post-test.

2) Tahap Pelaksanaan kegiatan yaitu: 
a. Pretest, untuk mengetahui dengan pasti sejauhmana pemahaman peserta pelatihan tentang teknik pop-up bagi pendidik anak usia dini.

b. Pemberian materi, antara lain konsep kreativitas, manfaat kreativitas, strategi stimulasi kreativitas bagi guru PAUD, pengenalan pop-up, jenis-jenis teknik pop-up dan teknik pop-up bagi guru PAUD.

c. Praktek teknik pop-up. Pada pelaksanaan praktek teknik pop-up peserta diajarkan membuat media pembelajaran berbagai teknik pop-up. Kumpulan media pembelajaran dari berbagai teknik kemudian dibuat menjadi buku pop-up.

d. Diskusi, menemukan masalah atau kendala dan mencari pemecahan bersama saat praktek teknik pop-up.

3) Tahap Akhir peserta mempresentasikan hasil karya teknik pop-up. Peserta juga diberikan post-test diakhir pelatihan.

Metode pengolahan data pada kegiatan ini menggunakan metode kuantitatif. Untuk menganalisis efektivitas keberhasilan kegiatan pelatihan dilakukan penilaian menggunakan kriteria kategori penilaian untuk melihat pemahaman peserta pelatihan terhadap materi teknik pop-up. Tabel 1. menunjukkan Kriteria Kategori Penilaian.

Tabel 1. Kriteria Kategori Penilaian

\begin{tabular}{clll}
\hline No. & & Skor & \multicolumn{1}{c}{ Kategori Penilaian } \\
\hline 1 & $1-20$ & & Sangat Kurang \\
2 & $21-40$ & & Kurang \\
3 & $41-60$ & & Cukup \\
4 & $61-80$ & Baik \\
5 & $81-200$ & Sangat Baik \\
\hline
\end{tabular}

Teknik analisis data menggunakan uji deskriptif dan uji deferensial berupa uji beda data berpasangan. Berikut rumus uji beda:

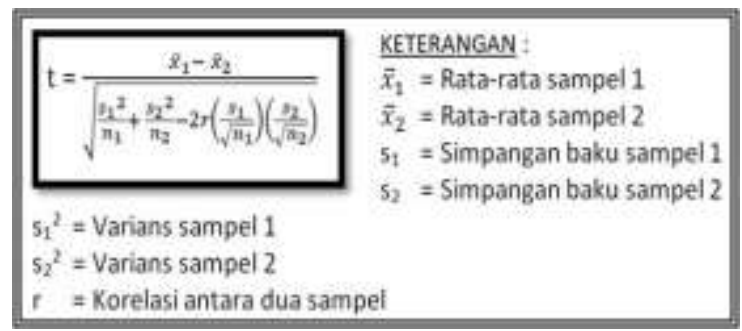

Gambar 1. Rumus uji beda data berpasangan

Rumus uji beda data berpasangan digunakan untuk menganalisis efektivitas yang terjadi sebelum dan sesudah pelatihan.

\section{HASIL DAN PEMBAHASAN}

Hasil pelatihan

Kegiatan pelatihan ini dilaksanakan di aula TK Tunas Bangsa Bandar Lampung, dengan pertimbangan lokasi di tengah kota dan mempunyai ruang yang luas. Peserta adalah guru-guru di Bandar Lampung dengan jumlah 25 orang. Diawal pelatihan peserta dibagikan pre-test untuk mengetahui pengetahuan dasar tentang kreativitas teknik pop-up sebelum pelatihan. 


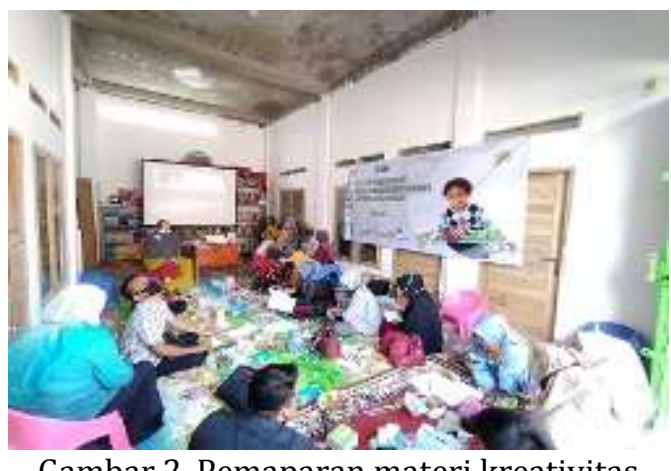

Gambar 2. Pemaparan materi kreativitas

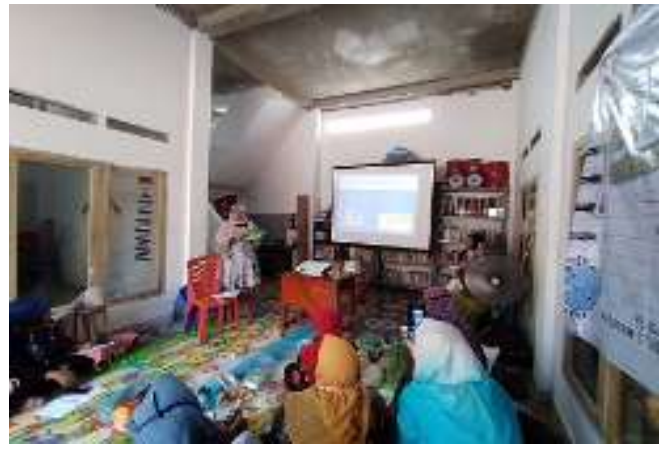

Gambar 3. Pemaparan materi pop-up

Setelah pre-test, materi pertama yaitu konsep dan manfaat kreativitas bagi guru PAUD. Materi ini adalah dasar dan bekal untuk memulai pembelajaran di PAUD. Materi kedua yaitu strategi stimulasi kreativitas bagi guru PAUD. Materi ketiga adalah pengenalan konsep teknik pop-up dan jenis-jenis teknik pop-up bagi guru PAUD.

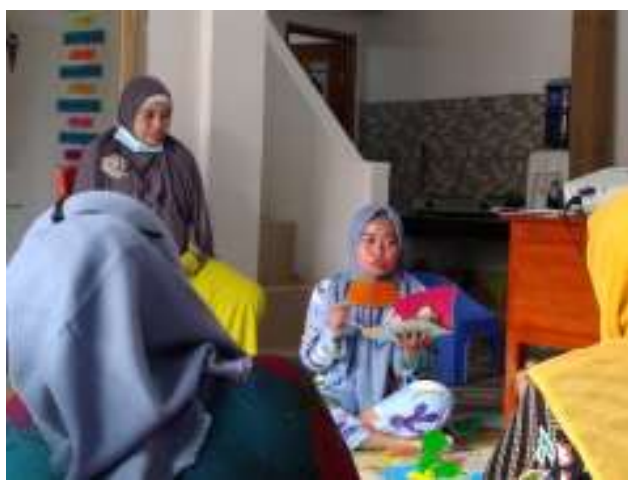

Gambar 4. Simulasi teknik pop-up

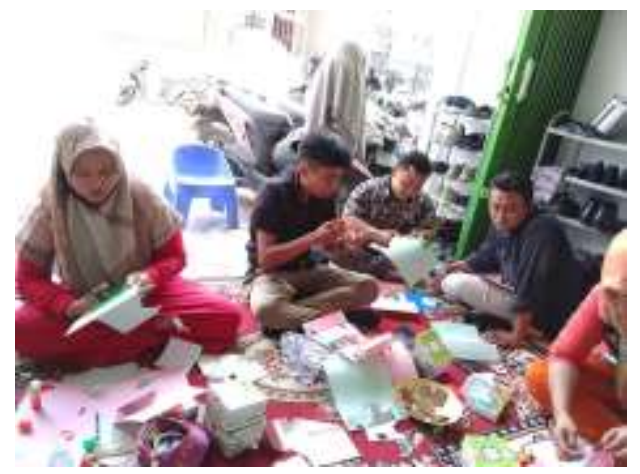

Gambar 5. Praktek teknik pop-up

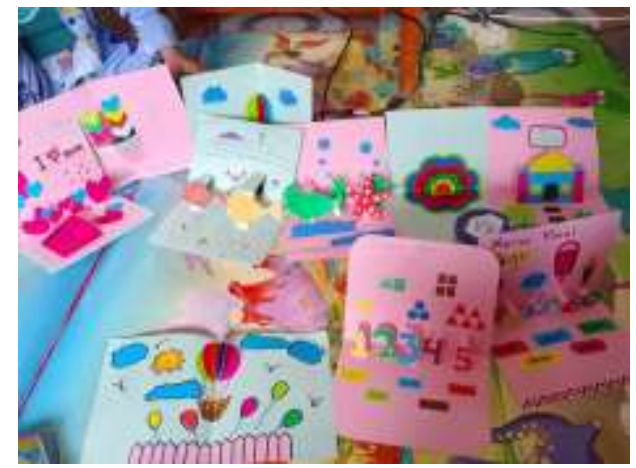

Gambar 6. Hasil karya peserta

Kegiatan terakhir yaitu simulasi teknik pop-up dan praktek teknik pop-up. Pada simulasi teknik pop-up pemateri mencontohkan setiap jenis teknik pop-up. Setelah itu, pemateri juga memperlihatkan contoh-contoh buku dari kreativitas teknik pop-up. Pada sesi terakhir, peserta mempraktekkan pembuatan media pembelajaran menggunakan teknik pop-up. Dalam pembuatan media pop-up peserta diberi kebebasan dalam menentukan tema dan jenis teknik yang akan digunakan. Selama pembuatan media pop-up berlangsung, peserta menyatakan sangat senang dan antusias mengerjakan media pop-up. Hal ini dikarenakan peserta mengungkapkan mendapatkan keterampilan baru yang belum pernah didapatkan. Selain itu, peserta juga mengungkapkan akan menggunakan media pop-up dalam pembelajaran di PAUD. Setelah peserta mempraktekkan secara langsung membuat media pop-up, peserta mempresentasikan pembelajaran menggunakan media pop-up yang dibuat dihadapan peserta lainnya. Diakhir sesi pelatihan, peserta diberikan post-test kembali untuk mengukur pengetahuan dan keterampilan yang didapatkan selama pelatihan. Berdasarkan hasil 
wawancara, seluruh peserta menyatakan pelatihan ini sangat efektif menambah keterampilan dan kreativitas dalam membuat media pembelajaran teknik pop-up. Hasil penelitian ini senada dengan hasil penelitian Barsihanor et al. (2020) dan Widyaningrum et al. (2021) menyatakan bahwa terjadi peningkatan keterampilan dan guru memberikan respon positif dan guru dapat mengembangkan kativitas selama pembuatan media pop-up.

\section{Penilaian Pre-Test dan Post-test}

Sebelum diberi materi pelatihan, para peserta diberi pre-test yang berkaitan dengan materi pelatihan. Tabel 2. Menunjukkan hasil pre-test dari peserta.

Tabel 2. Hasil Pre-Test Peserta Pelatihan

\begin{tabular}{ccc}
\hline Subjek & Skor pre-test & Kategori Penilaian \\
\hline 1 & 60 & Cukup \\
2 & 53 & Cukup \\
3 & 47 & Cukup \\
4 & 20 & Sangat kurang \\
5 & 53 & Cukup \\
6 & 67 & Baik \\
7 & 67 & Baik \\
8 & 60 & Cukup \\
9 & 60 & Cukup \\
10 & 60 & Cukup \\
11 & 57 & Cukup \\
12 & 60 & Cukup \\
13 & 70 & Baik \\
14 & 80 & Baik \\
15 & 67 & Cukup \\
16 & 40 & Cukup \\
17 & 40 & Cukup \\
18 & 33 & Cukup \\
19 & 40 & Cukup \\
20 & 20 & Sangat kurang \\
21 & 67 & Cukup \\
22 & 67 & Cukup \\
23 & 40 & Cukup \\
24 & 33 & Cukup \\
25 & 67 & Baik \\
\hline
\end{tabular}

Berdasarkan hasil pre-test terlihat bahwa tidak ada peserta mendapatkan skor pada kategori sangat baik. Terdapat 2 peserta (8\%) memiliki tingkat pengetahuan teknik pop-up pada kategori sangat kurang. Terdapat 5 peserta (20\%) memiliki tingkat pengetahuan teknik pop-up pada kategori baik. Terdapat 18 peserta (72\%) memiliki tingkat pengetahuan teknik pop-up pada kategori cukup. Artinya, rata-rata tingkat pengetahuan teknik pop-up peserta berada pada kategori cukup yang memiliki skor antara 40-60. Hal ini didukung berdasarkan wawancara data data pre-test pada saat pelatihan, peserta belum mengetahui teknik-teknik pop-up, tidak mengetahui cara membuat pembelajaran menggunakan teknik pop-up, peserta tidak mengetahui variasi media pembelajaran menggunakan pop-up untuk pembelajaran anak usia dini. Peserta juga menyatakan mengetahui buku pop-up yang dijual bebas. Sehingga, cukup penting untuk meningkatkan tingkat pengetahuan dan keterampilan peserta mengenai kreativitas teknik pop-up.

Setelah pembekalan materi dan pelatihan teknik pop-up, peserta kemudian diberikan post-test. Berikut Tabel 3 berisi rincian hasil post-test peserta pelatihan. 
Tabel 3. Hasil Post-Test Peserta Pelatihan

\begin{tabular}{ccc}
\hline Subjek & Skor post-test & Kategori Penilaian \\
\hline 1 & 93 & Sangat baik \\
2 & 73 & Baik \\
3 & 87 & Sangat baik \\
4 & 67 & Baik \\
5 & 87 & Sangat baik \\
6 & 87 & Sangat baik \\
7 & 93 & Sangat baik \\
8 & 87 & Sangat baik \\
9 & 80 & Baik \\
10 & 93 & Sangat baik \\
11 & 87 & Sangat baik \\
12 & 87 & Sangat baik \\
13 & 93 & Sangat baik \\
14 & 93 & Sangat baik \\
15 & 87 & Sangat baik \\
16 & 73 & Baik \\
17 & 73 & Baik \\
18 & 67 & Baik \\
19 & 73 & Baik \\
20 & 73 & Baik \\
21 & 87 & Sangat baik \\
22 & 93 & Sangat baik \\
23 & 73 & Baik \\
24 & 73 & Baik \\
25 & 87 & Sangat baik \\
\hline
\end{tabular}

Berdasarkan hasil post-test diketahui bahwa sebagian besar peserta (60\%) menyatakan meniliki pengetahuan pada kategori skor sangat baik setelah pelatihan. Sementara itu, sebanyak 40 persen peserta menyakatan memiliki pengetahuan pada skor baik setelah pelatihan. Selain itu, tidak ada peserta yang memiliki skor kategori sangat kurang, kurang maupun cukup. Dari hasil analisis ini menunjukkan bahwa terjadi peningkatan pengetahuan tentang kreativitas dan teknik pop-up. Bila dilihat dari hasil wawancara selama pelatihan, rata-rata peserta menyatakan bertambah pengetahuan dan keterampilan tentang kreativitas teknik pop-up. Peserta juga menyatakan bahwa teknik pop-up sangat bermanfaat untuk pembelajaran di PAUD dan mudah untuk dipraktek menjadi media pembelajaran.

Selanjutnya, hasil pre-test dan post-test dianalisis untuk melihat perbedaan antara sebelum pelatihan dan sesudah pelatihan. Hasil analisis skor sebelum dan sesudah pelatihan dapat dilihat pada tabel 4 berikut ini.

Tabel 4. Hasil Perubahan Skor Pre-Test dan Post-Test Peserta Pelatihan

\begin{tabular}{cccc}
\hline Subjek & Skor pre-test & Skor post-test & Perubahan skor \\
\hline 1 & 60 & 93 & 33 \\
2 & 53 & 73 & 20 \\
3 & 47 & 87 & 40 \\
4 & 20 & 67 & 47 \\
5 & 53 & 87 & 34 \\
6 & 67 & 87 & 20 \\
7 & 67 & 93 & 26 \\
8 & 60 & 87 & 27 \\
9 & 60 & 80 & 20 \\
\hline
\end{tabular}




\begin{tabular}{cccc}
\hline Subjek & Skor pre-test & Skor post-test & Perubahan skor \\
\hline 10 & 60 & 93 & 33 \\
11 & 57 & 87 & 30 \\
12 & 60 & 87 & 27 \\
13 & 70 & 93 & 33 \\
14 & 80 & 93 & 13 \\
15 & 67 & 87 & 20 \\
16 & 40 & 73 & 33 \\
17 & 40 & 73 & 33 \\
18 & 33 & 67 & 34 \\
19 & 40 & 73 & 33 \\
20 & 20 & 73 & 53 \\
21 & 67 & 87 & 20 \\
22 & 67 & 93 & 26 \\
23 & 40 & 73 & 33 \\
24 & 33 & 73 & 40 \\
25 & 67 & 87 & 20 \\
\hline
\end{tabular}

Berdasarkan hasil analisis, dapat dilihat sebagian besar peserta mengalami peningkatan setelah pelatihan. Perubahan skor dari sebelum pelatihan dan sesudah pelatihan pada rentang 13-47 poin. Artinya, pelatihan ini memberikan dampak peningkatan perubahan pengetahuan tentang kreativitas teknik pop-up. Selain itu, berdasarkan wawancara pada saat praktek, peserta juga menyatakan adanya perubahan keterampilan teknik pop-up, dari tidak bisa menjadi bisa. Selanjutnya, data pre-test dan post-test dianalisis lanjut untuk mencari kategori penilaian. Bila data pre-test dan post-test dikategorikan, maka dapat dilihat perbandingan pre-test dan posttest pada Tabel 6.

Tabel 6. Sebaran responden berdasarkan kategori pre-test dan post-test

\begin{tabular}{|c|c|c|c|c|c|}
\hline \multirow[t]{2}{*}{ No } & \multirow[t]{2}{*}{ Kategori } & \multicolumn{2}{|c|}{ Pre-test } & \multicolumn{2}{|c|}{ Post-test } \\
\hline & & $\mathrm{n}$ & $\%$ & $\mathrm{n}$ & $\%$ \\
\hline 1 & Sangat Kurang & 2 & 8.0 & 0 & 0.0 \\
\hline 2 & Kurang & 6 & 24.0 & 0 & 0.0 \\
\hline 3 & Cukup & 9 & 36.0 & 0 & 0.0 \\
\hline 4 & Baik & 8 & 32.0 & 10 & 40.0 \\
\hline 5 & Sangat Baik & 0 & 0.0 & 15 & 60.0 \\
\hline Total & & 25 & 100.0 & 25 & 100.0 \\
\hline \multicolumn{2}{|c|}{ Rata-Rata + Std } & \multicolumn{2}{|c|}{$\begin{array}{ll}10 \\
53.12 \pm 16.0\end{array}$} & \multicolumn{2}{|c|}{$82.64 \pm 9.04$} \\
\hline \multicolumn{2}{|c|}{ Min - Max } & \multicolumn{2}{|c|}{$20-80$} & \multicolumn{2}{|c|}{$67-93$} \\
\hline
\end{tabular}

Dari hasil analisis kategori pre-test sebelum pelatihan diketahui bahwa sebanyak 8 persen peserta masih memiliki skor pre-test pada kategori sangat kurang. Sebanyak 24 persen peserta memiliki skor pre-test pada kategori kurang. Sebanyak 36 persen peserta memiliki skor pre-test pada kategori cukup. Sebanyak 32 persen peserta memiliki skor pre-test pada kategori baik. Sementara itu, tidak ada peserta yang memiliki pemahaman teknik pop-up pada kategori sangat baik. Sebanyak 53.12 persen rata-rata peserta memiliki skor pretest pada kategori cukup.

Adapun setelah pelatihan, hasil analisis post-test diketahui bahwa sebanyak 40 persen peserta menyatakan memiliki pemahaman teknik pop-up pada kategori baik. Sisanya, sebanyak 60 persen peserta menyatakan memiliki pemahaman teknik pop-up. Sementara itu, setelah pelatihan peserta menyatakan tidak ada peserta yang memiliki kategori sangat kurang, kurang dan cukup. Artinya, berdasarkan hasil analisis peserta memiliki peningkatan pengetahuan terhadap pengetahuan kreativitas teknik pop-up. 
Selanjutnya, untuk melihat perbedaan signifikan antara sebelum pelatihan dengan sesudah pelatihan, dilakukan uji lanjut menggunakan uji beda. Berikut ini adalah hasil uji beda antara sebelum dan sesudah pelatihan.

Tabel 7. Hasil uji beda pre-test dan post-test

\begin{tabular}{clcccc}
\hline No & Keterangan & Rata-rata & Std & t & Sig. \\
\hline 1 & Pre-test & 53,12 & 16,00 & $-15,831$ & 0,000 \\
2 & Post-test & 82,64 & 9,04 & & \\
\hline
\end{tabular}

Berdasarkan hasil uji beda dapat disimpulkan bahwa terdapat kenaikan nilai rata-rata peserta sebelum dan sesudah dilaksanakan pelatihan. Hasil menunjukkan bahwa rata-rata nilai pre-test adalah 53,12 persen dan rata-rata nilai post-test 82,64 persen. Dari analisis kenaikan skor sebesar 31,52. Berdasarkan hasil diketahui bahwa ada hubungan signifikan positif $(r=0.867, p<0,05)$ pengetahuan pre-test dengan pengetahuan post-test. Artinya, kenaikan pengetahuan post-test erat kaitannya dengan materi pelatihan yang diberikan. Hasil uji beda menyatakan terdapat nilai signifikansi $0.000(\mathrm{p}<0.05)$ artinya ada perbedaan antara sebelum dan sesudah pelatihan. Hal ini menunjukkan bahwa terdapat perbedaan hasil dari sebelum pelatihan dengan sesudah pelatihan teknik pop-up.

Dari hasil analisis diketahui bahwa terdapat perbedaan signifikan positif antara sebelum dan sesudah pelatihan teknik pop-up. Artinya, terdapat peningkatan keterampilan teknik popup pendidik anak usia dini antara sebelum dan sesudah pelatihan. Hal ini, terlihat pada sebelum pelatihan masih banyak peserta pelatihan yang belum memiliki pengetahuan dan keterampilan teknik pop-up. Namun, setelah pelatihan peserta menyatakan memiliki pengetahuan dan keterampilan tentang teknik pop-up. Hal ini sejalan dengan kegiatan pengabdian (Puspitaloka \& Hasanah, 2020) yang menyatakan pelatihan pembuatan media pembelajaran pop-up book bagi guru TK menambah kompetensi baru dalam meningkatkan pembelajaran bahasa Inggris. Tidak hanya guru yang merasakan dampak pelatihan pop-up, namun siswa juga merasakan dampak pelatihan pop-up antara lain hasil pelatihan media pop-up juga berdampak pada siswa tunagrahita. Sari dan Kasiyati (2018) menyatakan bahwa teknik pop-up efektif dalam meningkatkan kemampuan mengenal bagian-bagian tubuh pada siswa tunagrahita ringan. Sementara itu, Fadiana dan Rosalina (2020) menyimpulkan adanya peningkatan rasa percaya diri pada siswa tunagrahita ringan dan sedang di SLB C Autis Negeri Tuban dalam hal unjuk diri menggunakan media pop-up dengan berani tampil di depan kelas, bercerita, dan menjawab pertanyaan, selain itu terjadi proses interaksi dan komunikasi dalam kegiatan pembelajaran antara pendidik dengan peserta didik dan sesama teman saat kegiatan unjuk diri berlangsung.

Teknik pop-up book bertujuan meningkatkan kreativitas pendidik anak usia dini. kreativitas pendidik anak usia dini sangat diperlukan dalam pengelolaan pembelajaran di kelas. Hal ini didukung penelitian Johan (2020) menyatakan bahwa upaya guru dalam membelajarkan setiap siswa berbeda-beda, hal tersebut bergantung kepada tingkat kreativitas guru dalam proses pengelolaan pembelajaran di kelas.

\section{KESIMPULAN}

Berdasarkan uraian yang ada pada hasil dan pembahasan, maka dapat dikemukakan kesimpulan dari hasil pelatihan ini adalah nilai pre-test rata-ratanya adalah 53,12 persen mengalami kenaikan hasil posttest menjadi 82,64 persen. Hal ini menunjukkan bahwa hasil dari sebelum pelatihan dengan sesudah pelatihan teknik pop-up mengalami kenaikan ataupun mengalami perubahan. Dari hasil uji beda dapat disimpulkan ada perbedaan signifikan efektivitas pelatihan teknik pop-up untuk meningkatkan kreativitas pendidik anak usia dini.

Berdasarkan hasil kegiatan pelatihan dan memperhatikan masukan dari peserta, maka diajukan saran-saran antara lain kegiatan ini dirasakan sangat bermanfaat, mengingat para peserta belum pernah mendapatkan kegiatan dengan materi seperti ini sebelumnya, sehingga 
dirasa perlu diadakan kegiatan pelatihan kembali dengan tema lain. Perlu dilakukan tindak lanjut agar para peserta dapat mengimplementasikan teknik pop-up bagi anak usia dini dalam proses pembelajaran di PAUD.

\section{UCAPAN TERIMA KASIH}

Penulis mengucapkan terima kasih kepada Universitas Lampung yang telah memberikan Hibah BLU Universitas terhadap kegiatan pengabdian ini.

\section{DAFTAR PUSTAKA}

Barsihanor, Hafiz, A., KMR, G. N., \& Budi, I. S. (2020). Pembuatan Media Pembelajaran Pop Up Book Bagi Guru Madrasah Ibtidaiyah. JMM (Jurnal Masyarakat Mandiri), 4(4), 588-594. Retrieved from http://journal.ummat.ac.id/index.php/jmm

Csikszentmihalyi, M. (1996). Creativity: Flow The Psychology of Discovery and Invention. New York: Harper and Collins Publishers.

Fadiana, M., \& Citra Dewi Rosalina. (2020). Peningkatan Rasa Percaya Diri Siswa Tunagrahita Melalui Pembelajaran Terintegrasi Semiotik Dengan Media Buku Pop Up. Dinamisia : Jurnal $\begin{array}{lll}\text { Pengabdian Kepada } & \text { Masyarakat, 373-383. }\end{array}$ https://doi.org/10.31849/dinamisia.v4i2.3940

Guilford, J. P. (1982). Cognitive psychology's ambiguities: Some suggested remedies. Psychological Review, 89(1), 48-59. https://doi.org/10.1037//0033-295x.89.1.48

Khamidah, N., Utaminingsih, S., \& Kanzunnudin, M. (2021). Pengembangan Media Pop Up Berbasis Kearifan Lokal Pada Kelas Iv Tema 8 Daerah Tempat Tinggalku Di Sekolah Dasar. Jurnal PAJAR (Pendidikan Dan Pengajaran), 5(2), 317-328.

Lismayanti, M. dkk. (2016). Pengembangan Buku Pop Up Sebagai Media Pembeljaran Pada Materi Crustacea Untuk SMA Kelas X. Penelitian Universitas Jambi Seri Sains, 18(0852-8349), 44.

Matin, R. H., Ety Rohaety, E., \& Nuraeni, L. (2019). Penerapan Media Pembelajaran Pop-Up Book Anak Usia Dini Pada Kelompok B Untuk Meningkatkan Kemampuan Keaksaraan Awal Di Tk Nusa Indah. CERIA (Cerdas Energik Responsif Inovatif Adaptif), 2(2), 49-56. https://doi.org/10.22460/ceria.v2i2.p49-56

Mohamad Johan, G. (2020). Media Pop-Up Book Untuk Melatihkan Keterampilan Menulis Karangan Siswa Sekolah Dasar. Visipena Journal, 11(1), 46-59. https://doi.org/10.46244/visipena.v11i1.1021

Pratiwi, I., \& Amelia, C. (2020). Penerapan Media Pop Up Book Untuk Meningkatkan Keterampilan Proses IPA Pada Mahasiswa PGSD. Jurnal Ilmiah Aquinas, 3(2), 287-295.

Puspitaloka, N., \& Hasanah, S. N. (2020). Pelatihan Pembuatan Pop Up Book Sebagai Media Pembelajaran Bahasa Inggris Bagi Guru- Guru Raudhatul Athfal ( RA ). IKRAITH-ABDIMAS, 3(1), 20-24.

Sari, Y., \& Kasiyati. (2018). Efektivitas Media Pop-Up Book untuk Meningkatkan Kemampuan Mengenal Bagian-Bagian Tubuh pada Siswa Tunagrahita Ringan. Jurnal Penelitian Pendidikan Kebutuhan Khusus, 6(1), 106-111. Retrieved from http://ejournal.unp.ac.id/index.php/jupekhu/article/view/101720

Solichah, L. A., \& Mariana, N. (2018). Pengaruh Media Pop Up terhadap Hasil Belajar Siswa pada Mata Pelajaran Matematika Materi Bangun Datar Kelas IV SDN Wonoplintahan II Kecamatan Prambon. JPGSD, 6(9), 1537-1547.

Sternberg, R. J., \& Lubart, T. I. (2014). The Concept of Creativity: Prospects and Paradigms. In Handbook of Creativity. https://doi.org/10.1017/cbo9780511807916.003

Streit, A. K., \& Erlyana, Y. (2019). Pelatihan Menggambar Dengan Mengeksplorasi Imaginasi Dengan Teknik Pop- Up (RPTRA Dharma Suci- Jakarta). Jurnal Pengabdian Dan Kewirausahaan, 3(2), 100-107.

Sutono, A., Winaryati, E., \& Hidayah, F. F. (2019). Pengembangan Pop-Up Book Food Chemistry 
For Kids. USA: Library of Congress Cataloging-in-Publication-Data.

Widyaningrum, H. K., Pratiwi, C. P., \& Listiani, I. (2021). Pelatihan Pembuatan Media 3D Dengan Menggunakan Media Pop-Up Book Sebagai Bentuk Peningkatan Gerakan Literasi Baca Dan Tulis Siswa Sekolah Dasar. Jurnal Pendidikan Dan Pengabdian Masyarakat, 4(1), 33-37.

Winarti, D., \& Setiani, R. (2019). Efektivitas Media Pop Up Book Pada Pembelajaran Cooperatif Tipe Make a Match Terhadap Hasil Belajar Matematika. JRPD (Jurnal Riset Pendidikan Dasar), 2(2), 136-142. https://doi.org/10.26618/jrpd.v2i2.2480 